\title{
Pengaruh Modernisme terhadap Aplikasi Ragam Hias pada Desain Masjid Salman-ITB Karya Ahmad Noe'man
}

\author{
Achmad Haldani Destiarmand \\ KK Kriya dan Tradisi Fakultas Seni Rupa dan Desain-ITB \\ Email: jakagledeg@super.com
}

\begin{abstract}
This research focuses on Achmad Noeman's views on the ornaments in Masjid Salman of ITB, which he designed in 1959. The research explores the socio- historical context of a designed artifact. The object was chosen due to preliminary observation and prescribed assumption that the role of ornaments in Noeman's mosque design were strongly reduced and differed compare to those of traditional mosque designs. Ornaments that used to be the heart of Islamic Art were no longer as vital and important in Noeman's mosque design. Accordingly, there should be reasons behind Noeman's mosque design that link him to the spirit of that time. The design of Masjid Salman exposes Achmad Noeman's strong determination in accomodating the popularity style of modernism that expose simplicity and functionality of an object; although as a moslem architect he had exposed to the more contempative and transcendent ways of object's aesthetics. Yet, he had not lost his spiritual touch, althoughhis Masjid Salman design is more into secular views of modernism. Based on observation of Noeman's works, it can be deduced that spirit of the time was influential in the design of modern mosque in Indonesia - as shown in Masjid Salman and Grand Masjid of Istiqlal in Jakarta. However, the shifting of Achmad Noeman's works to embrace modernism was not just results of mere copy-cat of a style but it came through a deep and inner contemplation of Achmad Noeman as an individual and academician architect.
\end{abstract}

Keywords: masjid; modernism; ornaments; style.

\section{$1 \quad$ Pendahuluan}

Salah satu fungsi seni paling awal atau tradisional adalah untuk tujuan vertikal (religius) yakni sebagai media untuk mencari, menyampaikan dan menciptakan nilai atau pesan keindahan dan kebenaran yang berhubungan dengan nilai keTuhan-an. Sebagaimana bentuk seni yang lain, seni 'untuk' Tuhan ini juga berkembang, bertransformasi dan bervariasi. Ada yang ditambahkan dan dikurangi, yang tetap atau mundur, progres atau regres sebagaimana hukum dan gerak kebudayaan: Pengertian kebudayaan dan tradisi kini lebih sering dipandang sebagai perubahan-perubahan atau defosilisasi [1]. Di sinilah muncul istilah seni modern yang diperlawankan dengan seni tradisional (pra-modern): 
seni pra-modern/tradisi itu melayani religi, ${ }^{1}$ sementara seni modern itu melayani ideologi [2].

Demikian pula dengan ragam hias pada arsitektur masjid atau 'rumah' Tuhan. Keberadaan ragam hias di sektor interior maupun eksterior masjid seringkali mengalami berbagai gejala di atas, bahkan pada konteks dan obyek tertentu keberadaan ragam hias dapat ditiadakan sama sekali.

Sebagai bagian dari budaya rupa, ornamen tentulah mempunyai bahasa rupa atau bahasa simbol. Pada satu saat ornamen itu dapat menggantikan makna ruang kosong. Namun juga sebaliknya bidang kosong dapat menggantikan makna ruang berornamen. Baik berornamen atau tidak keduanya mengandung nilai, fungsi dan tujuan tertentu. Jadi, peluang redundansi pengimbuhan ragam hias pada masjid sebanding dengan peluang redundansi peniadaannya. Baik itu ragam hias maupun kekosongan sama-sama dapat hadir untuk membangun sekian nilai, membangun sekian perenungan dan persepsi.

Dengan kata lain ragam hias yang pernah begitu sentral perannya dalam memperindah dan memaknai suatu bangunan suci ternyata tidak selamanya imun terhadap gejala transformasi bentuk, gagasan, maupun nilai sebagaimana manusia memperlakukan seni lain di tatar seni yang lebih profan: Salah satu bidang yang sangat pesat pertumbuhannya di era pasca-kolonial dan sering dipakai sebagi media simbolis di banyak negara adalah masjid: in our view, the treatment of its formal as well as functional characteristics serves as a barometer of taste, of identity and of symbolic values [3]. Sehingga siapa yang menggagas, merancang, dan melaksanakannyapun kini menjadi pokok-pokok nilai yang dapat mengkualifikasi nilai sebuah masjid.

Di konteks ini fungsi dan peran ragam hias diberbagai obyek, waktu dan wilayah budaya telah mengalami berbagai pasang surut. Horror vaqui dilawan oleh ornament is crime atau less is more yang lantas mendapat perlawan yang tidak kalah keras dari posmodernisme yang serba permisif dan membaur.

Jadi sejauh mana artefak seni masa lalu itu dapat mengungkap segi kemanusian dan kebudayaannya adalah pertanyaan yang juga dapat diajukan kepada manusia sekarang (modern): Bagaimana dan sejauh mana kehadiran dan

1 Studi yang cermat terhadap berbagai tradisi religius besar dunia memperlihatkan bahwa seluruh tradisi itu pada prinsipnya mempunyai semacam kepercayaan yang sama akan adanya struktur realitas yang hierarkis/bertingkat, yang biasanya digambarkan berupa lingkaran-lingkaran meliputi makrokosmosmikrokosmos, alam roh-alam jasad dalam formasi yang kompleks, seumpama bagaimana lingkup alam jasad yang juga menambahkan aspek rasa dan emosi, lalu alam pikiran juga menambahkan aspek kognisi dan logika yang melebihi alam jasad itu sendiri. Sementara, alam jiwa menyertakan juga esensi alam pikiran dan kognisi secara lebih ke spiritual. Akhirnya alam roh serba meliputi semuanya. [4] 
ketidakhadiran ragam hias modern khususnya pada masjid modern di Indonesia itu dapat mengungkap bagaimana manusia dan kebudayaan modern itu? Bagaimana hal itu mewujud dan dapat diuraikan secara teoritis maupun praksis berdasarkan analisis dan pendekatan estetika? Sebab menurut Holod [3] di akhir abad ke-20, gejala ekonomi multi nasional, masyarakat multi kultural, dan komunikasi global telah membawa ekspresi-ekspresi pada desain masjid sebagai sebuah bentuk silang budaya, sebagai reperesentasi transisi komunitas muslim di tengah meluasnya isu tentang heterogenitas budaya dan asimilasi, serta tentang hibridasi bentuk dan makna. Motivasi pembangunannyapun semakin beragam dari yang sangat paling fungsional hingga ke paling megah yang prestisius (Mercu Suar) semisal desain-desain di era mega arsitektur tahun 1940-1970-an yang bermotifkan nasionalisme para pemimpin besar pasca kolonial.

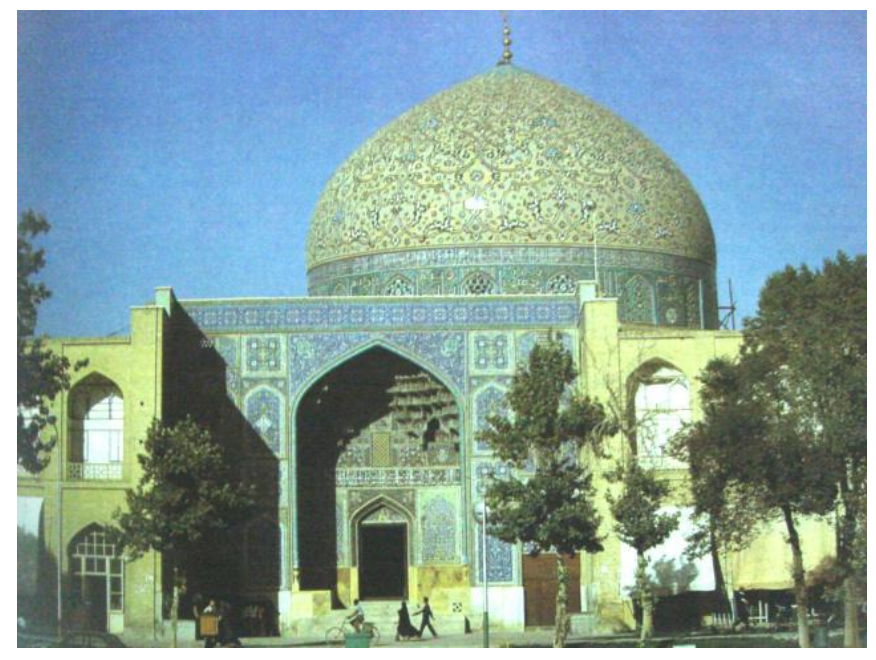

Gambar 1 Masjid di Istanbul, Turki (Sumber: Istimewa).

\subsection{Masjid}

Masjid (Arab=tempat sujud) adalah suatu bangunan, gedung, atau suatu lingkungan berpagar yang didirikan secara khusus sebagai tempat beribadah kepada Allah SWT, khususnya untuk mengerjakan shalat. Istilah masjid berasal dari kata sajada, yasjudu yang berarti bersujud atau menyembah. Masjid yang pertama dibangun adalah Masjid Madinah atau Masjid Nabawi (622 M/ 1H), sebagai salah satu dari 3 (tiga) masjid utama Islam di samping Masjidilharam (Makkah) dan Masjidilaksa (Palestina) [5].

Lay-out masjid banyak variasi dan perkembangannya, namun umumnya mempunyai kesamaan dalam hal adanya lapangan luas terbuka (sahan), 
sebagian dari sahan itu diperuntukkan untuk salat (musala-al haram), petunjuk kiblat, tempat imam memimpin salat (mihrab), dan tempat khatib berceramah (mimbar). Dewasa ini, dikenal juga komponen utama lain bangunan masjid, yakni kubah dan menara yang juga merupakan unsur serapan dari kebudayaan sebelumnya dan sesudahnya, seumpama kubah (Byzantium, Persia, Yunani, dan gereja) atau menara yang diserap dari bangunan lama di Suriah dan Persia. Karena posisinya sebagai bagian dari kebudayaan, maka ragam bentuk dan gaya arsitektur, interior dan eksterior masjid, sahan, musala, mihrab, mimbar, kubah, dan menara juga sangat bervariasi.

\subsection{Variasi Gejala Perkembangan dan Pasang Surut Ragam Hias Masjid di Indonesia}

Masyarakat Indonesia telah mengalami berbagai bentuk transformasi dari mulai era primitif, Hindu-Buddha, Islam, kolonial, dan pasca-kolonial. Ragam hias pada masjid dapat dijadikan indikator transformasi tersebut. Sebab di dalam istilah transformasi terdapat istilah dan pengertian proses perubahan suatu bentuk ke bentuk lain yang berlangsung dialogis, lama (evolutif) dan bertahap (hirarkis) antara suatu budaya donor dengan suatu masyarakat dan kebudayaan reseptor sehingga terjadi sintesa atau perubahan dengan berbagai variasi wujud dan tingkat kedalamannya baik secara tetap maupun sementara. Di dalamnya terdapat proses tawar menawar, dialog, kompromis, variatif, modifikatif. Transformasi dapat dilihat juga sebagai perkembangan sistem nilai, baik secara makro (Peradaban bangsa secara keseluruhandan) maupun mikro (seniman dan karyanya).

Alvin Toffler, misalnya, melihat proses transformasi sebagai ada 3 (tiga) gelombang (pertanian, industri, dan informasi) sementara gelombang ke-4 oleh Daniel Pink ditambahkan sebagai conceptual age. sebagaimana juga van Peursen membagi transformasi kebudayaan ke dalam tahap mitologis, ontologis, dan fungsional [6]. Berbagai gejala transformasi di atas berimbas juga kepada tahapan, ragam, proses, karakteristik, gaya, dan perilaku dan ekspresi hias-menghias di masyarakat Indonesia.

Apabila dihubungkan dengan masjid di Indonesia, unsur kubah misalnya, banyak yang masih mempertahankan bentuk atap bangunan Indonesia-Hindu atau Jawa berupa bentuk candi, limas, atap tumpang, ataupun joglo sebagaimana kita saksikan pada gaya arsitektur masjid Kudus, Demak, Banten, Cirebon, Solo, dan Yogyakarta. Di pasca kemerdekaan konten masjid sering disesuaikan dengan semangat zamannya, seumpama Masjid Syuhada di Yogyakarta (1952) yang unsur-unsur bangunannya dibentuk oleh angka keramat baru 17-8-45, sebagai monumen bagi para pahlawan (syuhada) kemerdekaan. Lalu masjid Al Azhar Jakarta (1950) yang bercorak Timur Tengah dan India, 
dihubungkan dengan politik dan kerjasama luar negeri Indonesia-Mesir yang sarat dengan semangat pendidikan, karena terdapat ruang belajar dan perpustakaan. Sementara masjid Salman ITB (1960-1972), sering disebut sebagai masjid yang sarat dengan nilai dan gagasan baru yang sangat berbeda dengan gaya sebelumnya. Menara dan kubahnya cekung, mirip tangan yang sedang menengadah serta sarat dengan kegiatan-kegiatan pendidikan, penelitian, dan pengabdian pada masyarakat, sebagaimana amanat dari tridharma perguruan tinggi. Di rentang alam kemerdekaan ini kita menyaksikan munculnya kegairahan membangun mesjid, dari yang sederhana hingga yang megah, dari yang berornamen dan yang sama sekali tak berornamen. Di penghujung era orde baru dan sesudahnya, ornamentasi masjid mulai nampak kembali dan akan semakin nampak, semisal pada masjid At-Tin (TMII-Jakarta), Al-Marakesh (Sulsel), Mesjid Raya Surabaya (Jatim), Cilegon (Banten), dan Kubah Emas di Depok (Jabar).

Akibat modernisasi yang membawa modernisme tadi, misalnya, maka ragam hias Indonesia pernah mengalami disfungsionalisasi sebagaimana nampak pada ketidakhadirannya di dalam unsur bangunan masjid Istiqlal (1955-1984, Jakarta), Masjid Salman ITB (1959-1972, Bandung), hingga ke Masjid Said Naum (1975-1977, Jakarta). Pada masjid Istqlal yang diprakarsai oleh penguasa Orde Lama, simbolisme semangat modernitas, nasionalisme, dan identitas baru, justeru dimediasi melalui nilai estetik lain seperti material beton, baja, dan idiom impor, dan bukan melalui ragam hias sebagaimana tradisi para penguasa lama. Sebagai bangsa yang cenderung ornamentik-simbolis, nilai estetik Masjid Istiqlal seolah meninggalkan sebuah tradisi seni menghias bangsa.

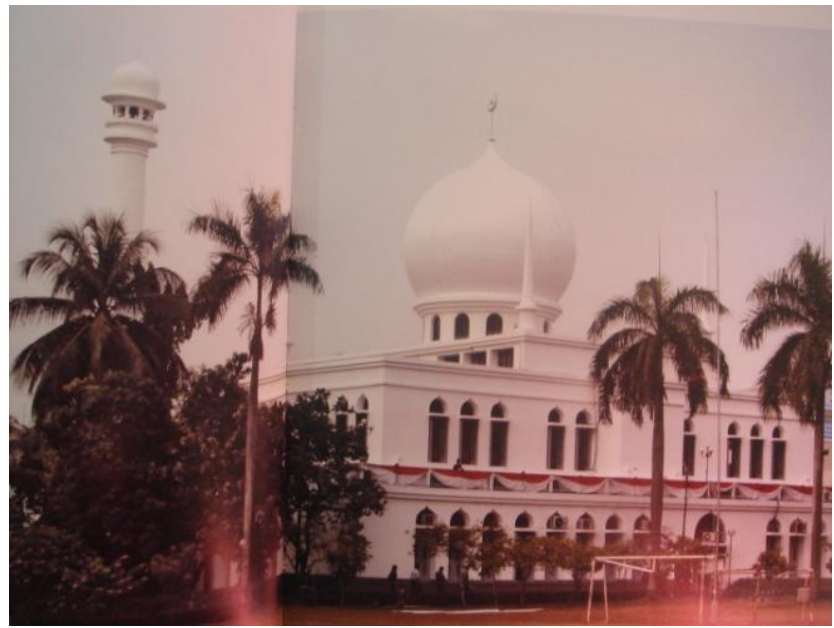

Gambar 2 Masjid dengan kubah bawang (Sumber: Istimewa). 
Namun, di sepanjang, penghujung dan pasca era Orde Baru yang bernuansa serba Jawa, ornamentasi masjid mulai nampak bergairah kembali semisal pada masjid At-Tin (TMII-Jakarta), Al-Marakes (Sulawesi Selatan), Mesjid Raya AlAkbar Surabaya (Jawa Timur), Cilegon (Banten), Pusat Islam, Jakarta, Masjid Agung Semarang, dan Kubah Emas di Depok (Jawa Barat). Semua seolah memperlihatkan antusiasme pra-modern, namun dengan spirit yang berbeda, di mana nilai-nilai lama, modernisme, postmodernisme, maupun modernkontemporer berbaur bersama dengan isu lokalitas, eklektisitas, dan sebagainya.

\subsection{Ragam Hias/Ornamen}

Terdapat beberapa istilah yang merujuk pada pengertian ragam hias seperti ornamen, ragi, dekorasi, corak, motif, iluminasi, dan sebagainya. Dalam kaitan khusus dengan Islam dan arsitektur masjid secara umum dapat dijelaskan sbb.:

Ornament: A form of surface decoration. The ornament may be reperesentational, vegetal, figural, or calligraphic (calligraphy). Ornament are incorporated into a decoration that systematizes and and classifies the area to be embellished. All forms of ornament occur in Islamic Art, with the calligraphic form clearly predominating and figural forms being of less importance [3]. Dari sumber lain dikatakan, bahwa ornamen merupakan komponen produk seni yang ditambahkan, atau dikerjakan pada produk seni itu, dengan tujuan menghiasnya. Seluruh ungkapan ini dipakai untuk tujuan ornamental [7]. Dalam seni Islam, ornamentasi atau zukhruf (dekorasi) bukanlah sesuatu yang sekedar ditambahkan secara superfisial pada karya seni yang sudah selesai tanpa ada arti apapun, juga bukan sarana pemuas selera atau kenikamatan semata, pun bukan sebatas sebagai pengisi ruang kosong semata, melainkan semua itu mempunyai fungsi yang sangat prinsip, yakni pengingat Tauhid, disamping fungsi keindahan, dan sebagainya [7].

\section{$2 \quad$ Konsep Masjid Salman ITB-Bandung}

Berbeda dengan desain Kampus ITB karya Henri Maclaine Pont pada 19181920 yang cenderung mengadopsi gaya tradisional Minangkabau dan HinduJawa, maka masjid Salman-ITB karya Ir. Achmad Noe'man (1959-1972+) justeru cenderung mengadopsi faham-faham modernisme yang sangat berseberangan sebagaimana juga letak masjid yang memang berada di seberang jalan kampus induknya. Posisi Achmad Noe'man sebagai inisiator recana induk, dosen, anggota panitia pembangunan masjid, reputasi, dan muslim yang dikenal taat cukup menjadi bekal dalam meyakinkan anggota panitia lain guna memperjuangkan opsi yang mengarah kepada interpretasi gaya dan prinsip modernisme yang jauh dari kesan dan nilai tradisional tadi. Peran klien dalam 
hal ini sesungguhnya sangat dimediasi dan dipengaruhi oleh sang arsitek sendiri (Gambar 3-4).

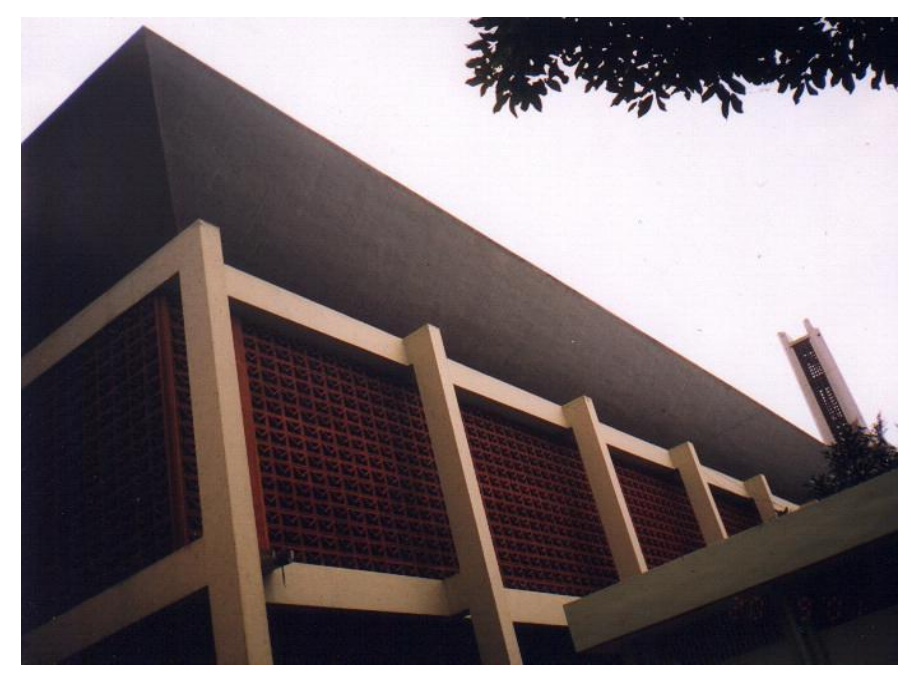

Gambar 3 Eksterior masjid Salman ITB (Sumber:Istimewa).

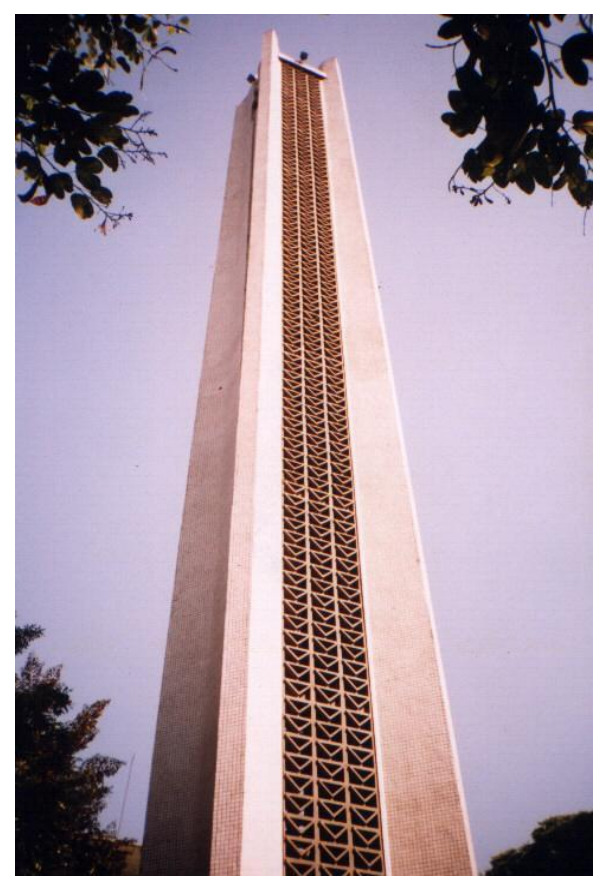

Gambar 4 Menara masjid Salman ITB (Sumber Istimewa). 
Karakter masjid Salman sangat terinspirasi oleh pemikiran kaum purisme yang tidak terperangkap oleh beban nilai tradisional seperti bentuk atap tumpang, garis lengkung ataupun kubah pada arsitektur masjid selama ini. In its architecture, The Salman Mosque makes no references to the past, nor does it evoke indigenous style - unlike, for example, The Said Naum Mosque in Jakarta instead, it employs a modern idiom that deliberately breaks with the past [3].

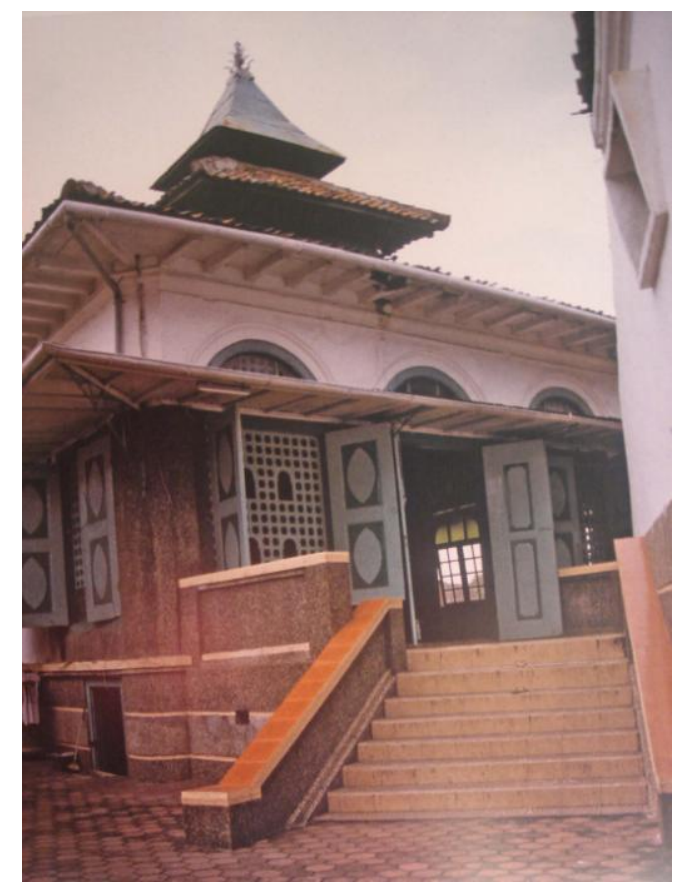

Gambar 5 Masjid dengan atap tumpang (Sumber:Istimewa).

Di masjid Salman, ruang spiritual dibangun melalui kesederhanaan, sementara nilai keindahan dinterpretasikan melaui beton sebagaimana bangunan International Style dari penganut modernisme pada umumnya. Detail dekoratif dilakukan dengan cara penuh pengendalian. Alat pencahayaan di ruang shalat sama dengan yang berada di beranda masjid yaitu berbentuk kubus dan ditempatkan di langit-langit. Meskipun banyak unsurnya mengikuti idiom International Style, namun terdapat juga pangaruh dari 'muqarnas' (elemen dekoratif tiga dimensional yang dapat berupa stalaktit, bergantungan secara bebas baik pada kubah, gerbang masuk, relung atau cerukan, dan permukaan dekoritif lainnya). Menurut Holod [3] ungkapan desain dari masjid Salman itu segaris dengan kaum sosialis progresif, atau quasi-sosialis sebagai aspirasi yang selaras dengan keinginan para pemimpin saat itu. Kecenderungan serupa juga dapat dideteksi dalam pengerjaan proyek lainnya sehingga dapat disebut sebagai gejala progresif di masanya. 


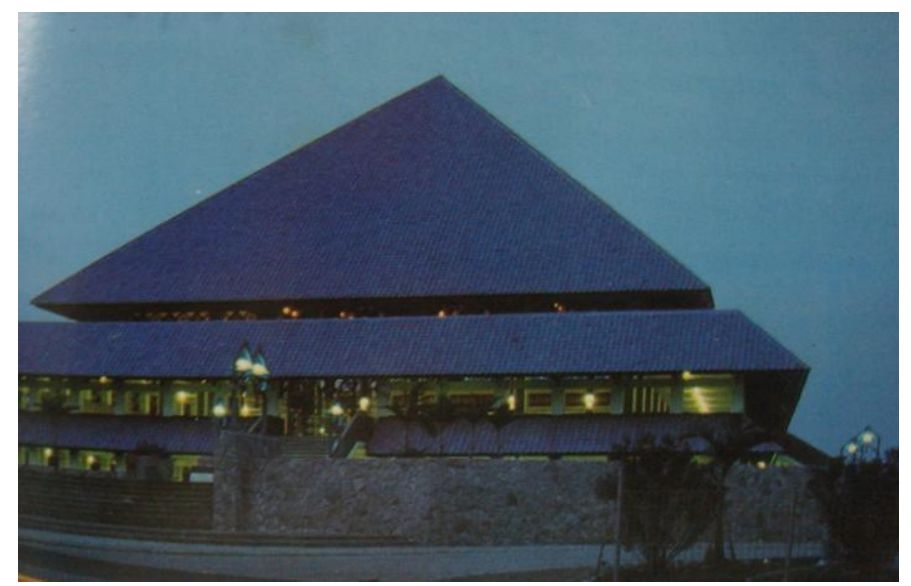

Gambar 6 Masjid Said Naum Jakarta (Sumber: Istimewa).

Menurut Achmad Noe'man ruh bangunan Islami sesungguhnya tidak terletak pada segi material, teknik, atau teori, melainkan lebih ke terhadap apa dan sejauh mana suatu desain dan implementasinya itu mampu mencerminkan pengabdian, berserah diri, dan ketakwaan kepada Allah dan hukum alam. Jadi, pertanyaannya adalah pada bagian mana saja pada masjid Salman yang mampu mencerminkan segi pengabdian, berserah diri, dan ketakwaan itu?

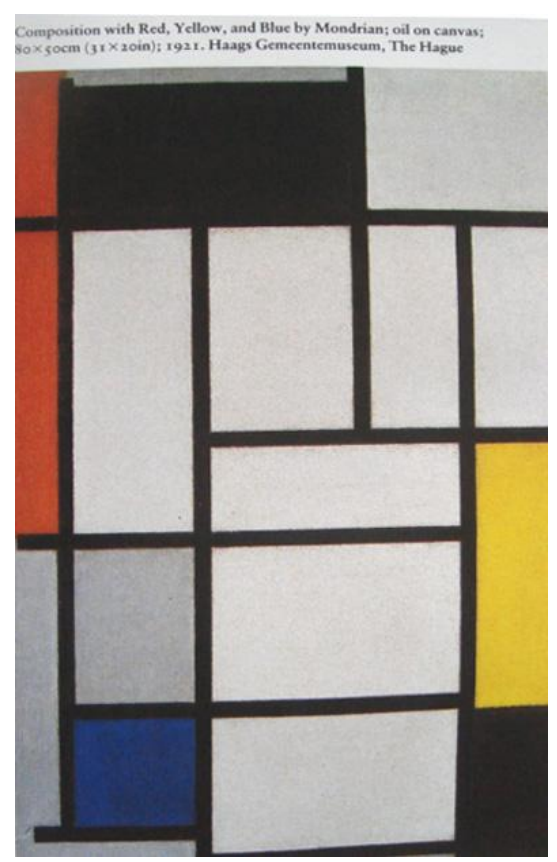

Gambar 7 Lukisan modern karya Piet Mondrian (Sumber: Istimewa). 
Modernisme, di dalam sejarah seni merupakan ideologi estetik yang pernah mendominasi praktek estetik selama 125 tahun. Merujuk ke era baru permesinan dan teknologi (industrialisasi) sebagai alasan untuk meninggalkan era anarki dan eklektik pada gaya-gaya Victoria, guna menuju ke bentuk dan gaya baru yang sesuai dengan situasi baru, yakni gaya modern. Para modernis, menyebut era ini sebagai modern age, yang dengan tegas melepaskan diri terhadap sejarah masa lalu dan nilai tradisi. Di sinilah antara lain muncul semangat "form follows function, ornament is crime, less, is more ...'. Di dunia Barat tendensi sekuler, dalam arti pergeseran orientasi dari otoritas transendental (abstrak) ke otoritas dunia nyata dan manusia muncul terutama sejak perkembangan ilmu pengetahuan pada zaman Renaissance (re-birth) tadi, di mana juga banyak penemuan benua baru yang semakin meningkatkan kepercayaan diri manusia sebagai pusat segala aktivitas peradaban (humanismeantroposentrisme) demi manfaatnya terhadap manusia itu sendiri. Akibat dari itu, dunia menjadi obyek penyelidikan rasional, yang lantas melahirkan ilmu dan teknologi. Dunia bukan lagi kosmos yang sakral sebagaimana keyakinan di zaman klasik, melainkan alam sekuler, universum yang dikuasai hukum-hukum mekanistik dan karena itu bisa diselidiki, dieksploitasi, direkayasa, digunakan untuk kepentingan manusia.

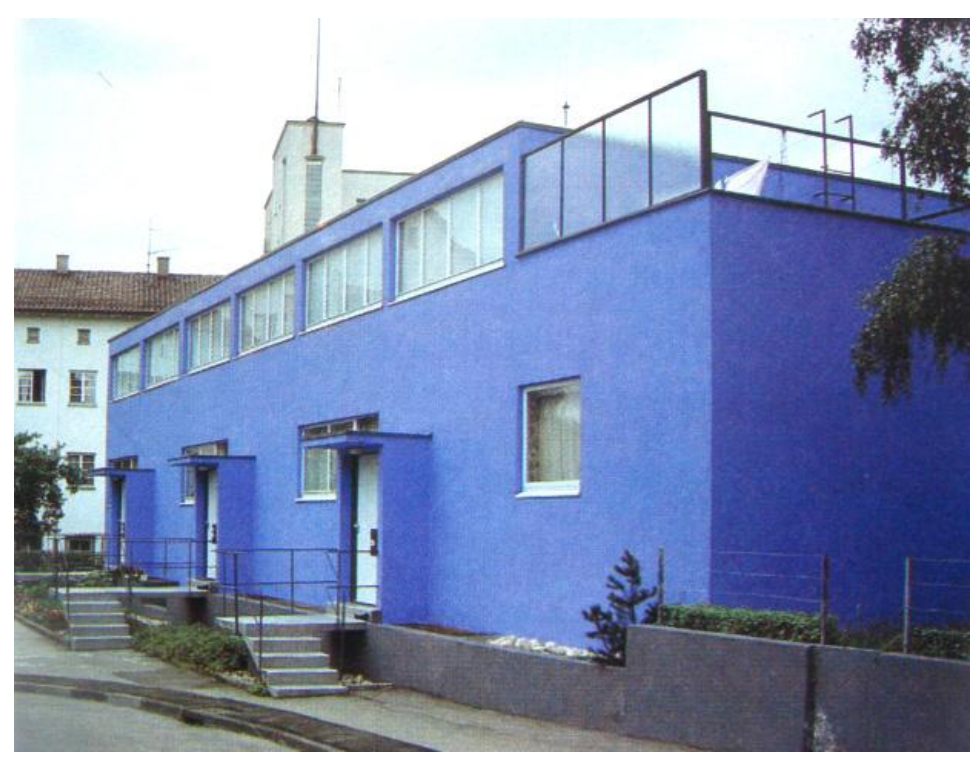

Gambar 8 Eksterior gaya modernist (Sumber Istimewa). 
Secara kamus, modern ${ }^{2}$ diartikan sebagai terbaru, mutakhir, atau sikap dan cara berfikir dan cara bertindak sesuai dengan tuntutan zaman. (KBBI 751). Tapi secara sejarah, ke mana istilah itu merujuk, sulit dipastikan dan sangat kompleks: Sukar sekali menentukan bilamana zaman modern dimulai. Yang jelas ialah bahwa pada abad ke-14 dimulailah krisis zaman pertengahan yang berlangsung hingga abad ke-15, dan bahwa abad ke-15 dan ke-16 dikuasai oleh suatu gerakan yang disebut Renaissance. [8]
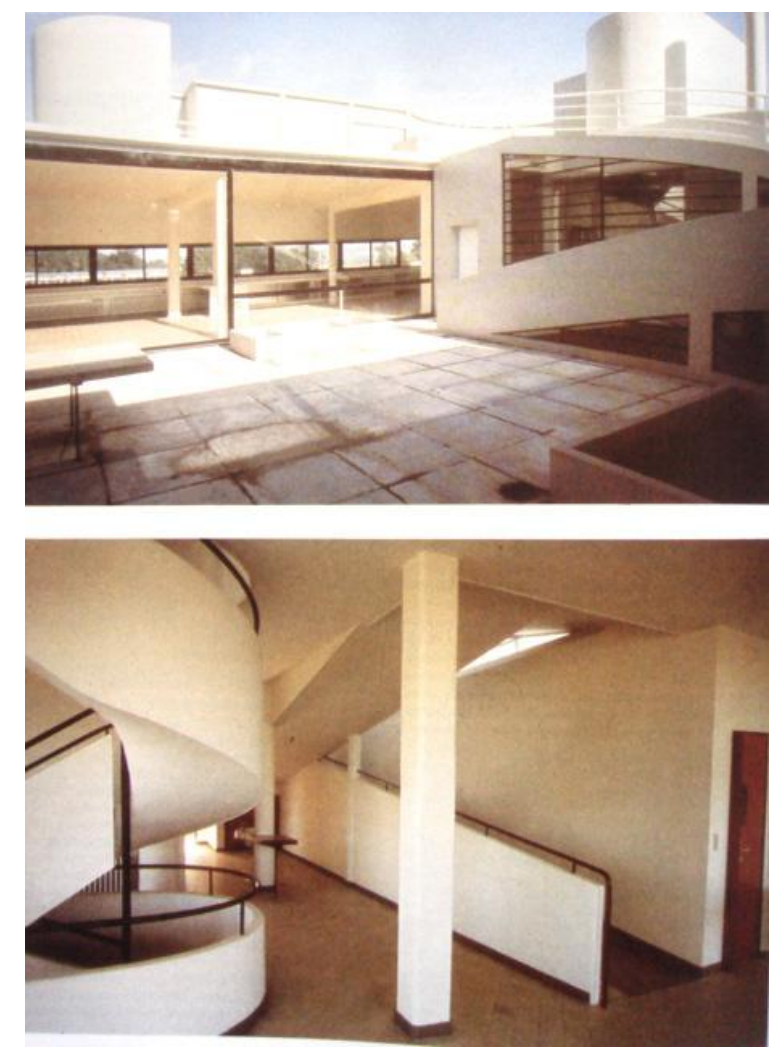

Gambar 9 Interior gaya modernist.

Di dalam wacana karya seni, istilah modernisme atau modern art itu merujuk pada modernisme sebagai gaya atau sebagai ekses dari faham-faham anutan, di mana ilustrasi gambar pada kasus arsitektur misalnya, memperlihatkan salah satu yang fenomenal, seumpama pada gaya internasional (International Style) atau Universal Style yang sangat teknologis, fungsional, sehat, ringan,

2 Pemikiran modern adalah peradaban Barat modern yang menolak sama sekali keberadaan struktur hierarkis dari realitas (pra-modern) dengan menggantinya melalui konsep realitas datar yang tersusun dari materi belaka, sehingga sangat cocok didekati secara sains. Maka berkembanglah filsafat resmi materialisme saintifik. [4] 
sederhana, ekonomis, logis, dan bersifat massal, dengan tokohnya a.l Mies Van Der Rohe, Walter Gropius (Bauhaus), dan lain-lain. Sementara pada lukisan, akan merujuk pada seni abstrak, ekspresionisme, konstruktifisme, kubisme, dadaisme, fauvisme, futurisme, impresionisme, minimal art, de stijl, surealisme, dan lain-lain.

Di era ini, ornamen dijauhi, dinilai primitif, berlebihan, dan tak berguna untuk digantikan oleh prinsip bentuk geometrik yang sederhana, jelas, jernih, homogen, murni, teratur, dan logis [9]. Sebab itu, faham ini menolak gaya regional kedaerahan, atau gaya nasional. Mereka malah melontarkan gagasan modernisme sebagai Gaya Internasional, sebab modernisme itu harus berlaku universal [10]. Dengan demikian, apa yang diungkapkan oleh sumber lain, terutama perihal seni, telah menemukan landasannya, mengapa seni di abad sekitar itu beranjak ke arah estetika saintifik: Di abad 19, perbincangan estetika bergeser ke arah scientific aesthetics (estetika ilmiah) yang mengembangkan metoda-metoda empiris, atau biasa juga disebut sebagai estetika modern, atau estetik ilmiah (yaitu ilmu empiris yang bercorak deskriptif, yakni berusaha menemukan fakta-fakta tentang seni serta kegiatan, citarasa, dan pengalaman manusia mengenai seni, menjelaskan proses-proses psikologis yang berhubungan dengan semua itu dan menguraikan berbagai seginya yang tetap dan berubah-ubah) [11].

Di Indonesia modernisme telah membentuk ragam wujud transformasi di bidang ornamentasi dengan kadar penghayatan, teknik, dan material berbeda, sehingga sebagimana pengaruh kebudayaan luar sebelumnya, derajat modernisme di Indonesia menampilkan wujudnya sendiri yang kemurnian dan konsistensinya acap dipertanyakan.

Secara kamus, modern ${ }^{3}$ diartikan sebagai terbaru, mutakhir, atau sikap dan cara berfikir dan cara bertindak sesuai dengan tuntutan zaman [12]. Tapi secara sejarah, ke mana istilah itu merujuk, sulit dipastikan dan sangat kompleks: Sukar sekali menentukan bilamana zaman modern dimulai. Yang jelas ialah bahwa pada abad ke-14 dimulailah krisis zaman pertengahan yang berlangsung hingga abad ke-15, dan bahwa abad ke-15 dan ke-16 dikuasai oleh suatu gerakan yang disebut Renaissance. [8]

\footnotetext{
3 Pemikiran modern adalah peradaban Barat modern yang menolak sama sekali keberadaan struktur hierarkis dari realitas (pra-modern) dengan menggantinya melalui konsep realitas datar yang tersusun dari materi belaka, sehingga sangat cocok didekati secara sains. Maka berkembanglah filsafat resmi materialisme saintifik. [4]
} 


\section{Kesimpulan}

Bahwa kenyataannya modern age, yang melepaskan diri terhadap sejarah masa lalu dan nilai tradisi juga berimbas pada gejala dunia perancangan di Indonesia yang indikatornya nampak pada didevaluai, dieliminasi, ataupun dialienasinya ragam hias pada arsitektur, termasuk arsitektur masjid Salman karya Ir. Achmad Noe'man. Disini a.l dalam konteks nilai luar semangat form follows function, ornament is crime, dan less, is more Begitu nampak berada dipihak sang arsitek. Bagaimana gaya seni yang bertendensi sekuler itu dapat diyakinkan kepada klien merupakan nilai tersendiri bagi sumbangsih konsep-konsep baru di luar sekularisme yang dalam hal ini sangat dipahami, didalam, dan direnungkan oleh Achmad Noe'man dengan mengatakan, bahwa Menurut Achmad Noe'man ruh bangunan Islami sesungguhnya tidak terletak pada segi material, teknik, atau teori, melainkan lebih ke terhadap apa dan sejauh mana suatu desain dan implementasinya itu mampu mencerminkan pengabdian, berserah diri, dan ketakwaan kepada Allah dan hukum alam. Dengan demikian, dalam kebudayaan Islam baik bidang ragam hias maupun bidang kosong mempunyai peluang pemaknaan spiritualitas yang sama tingginya, sebagaimana juga transendensi yang dicapai oleh obyek dan seni budaya lain seumpama pada bidang kosong yang terdapat pada candi Borobudur, pada batik kelompok iket destar dan kemben yang dikelilingi motif modang, mlinjon pada motif parang, dan bahkan kain simbut di baduy atau poleng di Bali, atau pakaian ihram pada saat ibadah haji.

\section{Daftar Pustaka}

[1] Zainuddin, Imam Buchori. 2001. Jurnal SRD, I, p. 15.

[2] Bambang Sugiharto, Seni dan Religi Kini, Sebuah Refleksi Filsafati, Paper makalah STSI, p. 1.

[3] Renata Holod. 1988. Islam: Art and Architecture, pp. 7,154,155, 627.

[4] Fritjof Capra. 1975. The Tao of Physics, xiv-xv. Shambala Publications.

[5] Ensiklopedia Islam, Jilid 3.

[6] Agus Sachari. 2000. Wacana Transformasi Budaya, p. 79-81, Penerbit ITB.

[7] Isma'iel L al-Faruqi. 1992. Atlas Budaya Islam, p. 412. Mizan.

[8] Harun Adiwijono. 1979. Sari Sejarah Filsafat Barat, 2, p. 11, PPIP Duta Wacana.

[9] Hendar Putranto. Cultural Studies, h. 91

[10] Jim Supangka. Refleksi Seni Rupa Indonesia: 108 
[11] The Liang Gie. 1976. Garis Besar Estetik (Filsafat Keindahan), Penerbit Karya, Yogyakarta.

[12] Kamus Besar Bahasa Indonesia, p. 751. 